\title{
How Successful Is Naturalism? Talking about Achievements beyond Theism and Scientism
}

\author{
Thomas Sukopp \\ Technical University of Braunschweig
}

$\mathrm{T}$ o state it up front: I am a naturalist. I do not think that this statement is more than a confession at the moment. Confessions are legitimate, but of course they should not supersede reasons. I therefore should have good arguments in which respects naturalism is successful or at least might be successful. My task is threefold: I have to explain what I mean by using the slippery word "naturalism". I will also argue that we disagree not only because of fruitless logomachy. I will define naturalism as the-hopefully fruitful-middle between a narrow-minded and self-destructing scientism on the one hand and a tradition in philosophy that is primarily occupied with its own history on the other (1). I deny the thesis that we should not spend much time on explications. Some of my opponents like Nancey Murphy or Michael Rea (both in this volume) define naturalism in such ways that are not acceptable. I will return to this point. To put it metaphorically: Naturalism is neither an impasse, nor a one-way street or a highway.

By arguing against Quine I will try to attack a position that results in inconsistencies or is even self-refuting. This section leads to challenging problems naturalism should deal with, e. g. normativity or the limits of scientific explanations (2).

The third and final chapter sketches answers to the question of this volume: "How successful is naturalism?" I will give examples for success as well as for serious problems that indicate where naturalism is not successful (3). This tour-de-force-ride is inevitably abridging. ${ }^{1}$

1 I should say that in my point of view the two main fields of research about naturalism and non-naturalism are: Metaphilosophical implications of naturalism/ 


\section{WHAT IS NATURALISM?}

"Tell me, what do you think about naturalism?" Whether one is a naturalist or not is no "Gretchen-Question" (see Faust I by Goethe). I therefore do not twirl like Faust did when Gretchen asked him. To say "Sure, I am a naturalist" should not be the end of a discussion but the beginning of one. This label neither means that someone has had a "philosophical coming out" nor that we of course agree with some naturalistic "wisdoms" which are-taken as serious theses-more than platitudes. A "single naturalism" does not exist. I found at least 30 different terms of "naturalism". Are these terms merely different designations? No, things are different.

I am not very much interested in doing philosophical taxonomy, but it has to be done. First, naturalism is not only, but also, a research program and can be identified by various theses. I only can give some hints why we should be careful with naturalistic labels. On the one hand, naturalism and their opponents spend too much time building straw men (see e.g one famous dictum of Sellars). On the other hand, naturalism tends to be an ideological point of view, the German term "Weltanschauung" fits better (see e.g. Keil \& Schnädelbach 2000).

\subsection{Naturalism: Levels}

I-like many others-distinct between ontological, methodological and epistemological (in a narrow sense) naturalism. We might add metaphilosophical or analytical naturalism. Here I leave these and other subtleties aside. Nevertheless, this classification is plausible. Ontology, epistemology and methodology raise questions of different complexity. And they interdepend in a multifactorial mode. Ontology is the most basic discipline because it asks what exists at all. (Therefore ontological austereness - "anaemic ontology" - as a naturalistic attitude is out of place.) What do we know about the existing entities? That's one central epistemological question. Finally methodologists ask for strategies which lead to knowledge.

non-naturalism and "weltanschauliche", e.g. ideological, consequences, entirely based on anthropological views. 
Of course, things are not that simple. The relationship between ontological, epistemological and methodological naturalism is no simple relation, since epistemology includes ontology and so on. An exponent of a specific ontology, e.g. physicalism, will certainly debar some epistemological questions, but its epistemology does not completely result from its ontology. A defender of eliminative materialism does not ask for the effectiveness of "mental things", because they do not exist. After these longer preliminaries let us classify naturalism. At the end of chapter 1, I will outline naturalism as a research program. I hope that my disambiguation will partly clear up "the lack of clarity" which Nancey Murphy (in this volume footnote 1) notices in view of common notions of "naturalism".

\subsubsection{Ontological naturalism}

A weak ontological naturalism is compatible with supernaturalism. It does not explicitly eliminate any possibility of a "higher" realm, of fundamental other nature and habit, beyond our - by (natural) laws accessible-world. This realm may be called a transcendent sphere over or beyond the world. Our supernaturalist, on the other hand, does not expressly assume such a realm. Consequently his supernaturalism is, in the last analysis, a worldimmanent naturalism. This ontological "naturalism" is too weak to deserve the label "naturalism". (Of course I do not suggest to affix a seal of "proven quality" on a naturalistic position simply because we name it this way.) Who denies such a weak "naturalism", since it claims too much? I guess not too many philosophers.

Strong naturalism asserts that the distinction between nature and a realm over or beyond nature is preposterous. "World", "cosmos" or "universe" include every actually existing "thing". There is no place (and space) for supernatural entities. This strong naturalism is a justifiable, partly justified position that even can be tested when it raises empirical claims. It surely has metaphysical elements, e.g. referring to "world", which is often, but not necessarily, combined with realistic positions. This naturalism is no arbitrary supposition but rather follows from methodological principles of science. In consequence of these well-known and widely accepted principles, hypotheses and theories should be testable, or-for typical philosophical issues_criticizable. 
Whatever it is we would like to test, we have to interact directly or indirectly. We can, in turn, only interact with systems which operate according to (natural) laws (see e.g. Bunge \&, Mahner 2004).

Following this strong ontological naturalism, long lists tell you what does not exist: God, Gods, human or other souls as pure substrates, angels, demons, ghosts, miracles, telepathy or other typical transcend entities. ${ }^{2}$ For a short positive list of what exists, see e.g. Quine, who offers a very short list: Matter and classes. This is in fact an "ontological desert" (Koskinen 2004) and even the naturalist, including the author of this paper, thirsts for some ontological commitment. Other naturalistic ontologies are richer (cf. e.g. Bunge \& Mahner 2004).

\subsubsection{Epistemological naturalism}

Constitution, awareness and justification of knowledge about the world is a process that can be developed by science (and humanities and other intellectual efforts; see e.g. Hedrich 1998, 26, or Kornblith 2002, Goldman 1994a and 1994b). Every defender of this position should also hold the view that we can identify a "package deal" consisting of ontological naturalism and moderate methodological naturalism. The latter insists that if knowledge-generating processes are part of the one and only (natural) world, and if they are gained partly by scientific methods, then we trust epistemologically that science sometimes helps us to answer epistemological questions. I will return to this point in Chapter 3.

\subsubsection{Methodological naturalism}

To cut a long story short: Methodological naturalists (see e.g. Philosophers like Goldman, Kitcher, Koppelberg, Kornblith, Laudan, Quine or Vollmer) rarely claim that science (i.e., natural sciences like physics, chemistry and biology) only and exclusively govern our methods in a form of an "autarchy" (against this view see e.g. Rea 2007, in this volume). Methodological naturalism should not be seen as tantamount to scientism. (See e.g. Goldman 2006 about the social dimensions of research and

2 This list includes not only entities. I do not intend to mix or confound categories. A generous reading of "miracles" in this respect could be: An entity that is indispensable for the existence of "miracles" is e.g. a Christian God. 
acquiring knowledge). Methodological naturalism is nevertheless not "harmless" (Almeder 1998), because it emphasises the continuity of philosophy with science (and humanities). We could e.g. see human reason as a fallible and empirically criticisable capability.

After this very brief sketch, let me outline an approach that is quite helpful in distinguishing between moderate and radical methodological naturalism. Dirk Koppelberg (2000, S. 82f.) formulates this species of naturalism as a package of three theses. The first one suggests that philosophy is no adequate foundation of sciences. It rejects any "Prima Philosophia". Secondly, philosophy "has no epistemically privileged point of view compared with science (and humanities)" (Koppelberg, see above). Finally, the third thesis formulates and demands the application of scientific investigations and results within philosophy. I will try to show in Chapter 3 that these claims are justified.

In order to distinguish methodological naturalism from more traditional epistemology, we picture the latter by seven theses according to Koppelberg:

(1) The methodological starting point of epistemology is the analysis of our ordinary everyday-notions about knowledge and beliefs.

(2) Epistemology makes use of terms and norms and formulates principles and aims that are not completely included in science.

(3) Epistemology has genuine philosophical methods and evidence.

(4) Epistemology has rules and norms which are logically independent from and prior to sciences.

(5) Epistemology avails not at all to scientific results and discoveries.

(6) Epistemological results (e.g. knowledge, justified beliefs) are epistemically fundamental in comparison with scientific results.

(7) Epistemology itself is logically independent and prior to science. 
The more of these theses we subscribe to, the more traditional is our view about epistemology. A methodological naturalist would-at the mostopine that theses (1)-(4) are correct.

One point is-hopefully_plausible by now: It is in fact not fair to characterise all naturalists as being forced by methodological considerations to see science as the only avenue to truth (against this view, see Rea 2007, Chapter 2). Solely Quine and some admirers (see Chapter 2) hold a replacement thesis (that means the reformulation of all legitimate epistemological questions in scientific problems as an actually conducted program) that is often being criticised as unsound, overdrawn and incoherent (see e.g. Almeder 1998 or Keil 2003). The latter argues coherently that Quine-despite his rhetorical efforts-does not do empirical psychology but rather philosophy (see also Sukopp 2006a, Chapter 4).

Perhaps you are looking for a simple summarizing "formula". I cite exemplary the Internet Encyclopedia of Philosophy:

Naturalistic epistemology is an approach to the theory of knowledge that emphasizes the application of methods, results, and theories from the empirical sciences. It contrasts which approaches that emphasize a priori conceptual analysis or insist on a theory of knowledge that is independent of the particular scientific details of how mind-brains work. (Wrenn, 1$)^{3}$

\subsection{Is naturalism a research program?}

It certainly is. Perhaps it is helpful to emphasise that a research program cannot only be fruitless or "degenerative" (Lakatos), but object of revision because some of its theses turn out to be incorrect. It is no contradiction to state both: Naturalism is a research program and consists of theses (against this, see Rea 2007, Chapter 1). One example is given by Gerhard Vollmer, who advocates an ambitious naturalism: His "all-inclusive" cosmologicalanthropological world-view combines post-popperian pancritical rationalism with hypothetical realism. He puts his position in twelve theses

3 I would like to add two points: First, not only empirical sciences are acceptable within a naturalistic point of view. Second, naturalists disagree about the necessity of a-priori-knowledge. Philip Kitcher is a naturalist and thinks that we cannot disband a-priori-knowledge. 
(see e.g. Vollmer 1994). The following six theses are essential. Vollmeraccording to his own words-should revise his view fundamentally, if one of the following theses turns out to be deficient (Vollmer 1994, 217):

(1) Use as little metaphysics as possible.

(2) Opine for "minimal realism" according to which a world without human beings could exist. (In fact Vollmer is a hypothetical realist.)

(3) Everything consists primarily of matter, or rather, energy.

(4) Real systems are build up from simple parts.

(5) Instances which transcend all experience-that means perception plus other sources of empirical knowledge-do not exist. Therefore miracles do not exist.

(6) Cognitive efforts do not exceed nature.

The shortest possible formula of this naturalism labels it with two characteristics: universality (Everywhere in the world everything can be perfectly rationally explained, in German: "Alles in der Welt geht mit rechten Dingen zu") and the restricted use of possible means, when we try to explain or give reasons for something.

\section{AGAINST QUINE: DEFENDING NATURALISM BY AFFRONTING IT}

Some naturalists are carrying naturalism too far, they are too radical. I will briefly outline one famous example, Willard Van Orman Quine, which shows naturalistic incoherence or even inconsistency ${ }^{4}$ caused by scientific

4 Consistency problems are raised by calling Quine's position e.g. "self-defeating" (Moser; Yandell 1996). Accordingly, he reverts to positions that he should not accept (physicalism, empiricism). See also Almeder's (1998) incoherence thesis: after Quine's replacement thesis, all answers to legitimate epistemological questions are distilled by scientific methods when we are doing science. The point is that the replacement thesis is no completely scientific assertion, therefore self-refuting. Almeder (1998) calls it "self-defeating" and inconsistent (see also Sosa 1983; Sagal 1987 or Stroud 2001). Quine_no wonder-rejects these critiques. He argues for a kind of holism that is more complex than most critics expect. Furthermore, inconsistency seems to be a logical, not an ontological problem. Logical defects 
prejudices and discrepancies between rhetoric self-ascription vs. the way Quine's own philosophy is actually carried out. In order to avoid boring the readers, I should focus on one rarely elaborated argument (2.2). First, I will have to reject Quine's famous argument for embedding epistemology in psychology (2.1). For further details cf. e.g. Hahn \& Schilpp 1986, Moser \& Yandell 1996, Almeder 1998, Keil 2003, Sukopp 2006a, Chapter 4.

\subsection{Quine's argument for embedding epistemology in psychology}

Traditional epistemology, according to the story Quine tells us, was searching for a safe fundament of human knowledge. This search was in vain. (That's by the way the shortest possible manner to simplify about 400 years of epistemological efforts. One tenet was to refute Descartes sceptical argument. All the attempts of refutations or rejections have failed. Even in mathematics knowledge is not as safe as some of us desire [see e.g. Almeder 1990, 264].) Since Hume we deal with the problem of induction. Hume shows us clearly that knowledge based on sensory data and perception also does not exist. Hume's argumentation claims that "Knowledge by Induction is not justified" (Hume 1982, 49-58), but rests on "customs" and "habits" (Hume 1982, 62), gets via Quine additional explosiveness.

If we-like Quine-neglect the distinction between analytical and synthetic propositions, and every proposition is synthetic, then "Hume's argument casts a long staggering cloud" over our efforts to give sceptics an adequate reply (Almeder 1990, 264). According to Quine, no proposition at all can claim to be safe knowledge. Therefore Quine concludes that traditional epistemology is dead. We have no "first Philosophy" and no pure philosophical truth, which justifies scientific or philosophical methods or serves as a grounding. This whole argumentation is viciously circular, because we have to assume- though we know better-a-priori-knowledge to identify and refute a-priori-knowledge.

What is really wrong with Quine's epistemology? His "settling for psychology" is a result of some deep insights (e.g. labeled by holism and

could not yet be demonstrated persuasively. Quine himself is not acting like a scientist. He sees place for "technology of truth-seeking" and for (restricted) norms. 
underdeterminacy) and even more prejudices (behavioristic psychology, the role of social constraints in epistemology) and misinterpretations (the status of what he calls "empiricism" and the role of norms). His agenda of epistemology-put in a few words-is this: If you are an epistemologist and your aim is to clarify the basic grounds of empirical sciences, than you should do psychology and exert the methods of science. (For the sake of the argument, I concede that every italicised term is clearly defined and Quine can confirm his ambitious program.) Then, Quine goes on, epistemology will be a branch of science, for it can only clarify-by using scientific methods-the sources and growth of human knowledge. Epistemology should be and will be descriptive psychology.

The most striking argument contra this "radical cure"-prescribed against the will of the "patient" philosophy_-is that Quine is simply inconsistent, while he is doing what he should not do: He acts like a philosopher and only talks like a "real" naturalist. I merely mention his slogan "Epistemology should be and will be descriptive psychology". This is certainly no empirically distilled proposition, but a result of philosophical (methodological and metaphilosophical) reflection.

5 Quine's notion of “empiricism" poses several questions. Here is one of them: his reference to evolution conflicts with his notion of empiricism. First, Quine is speaking of "subjective norms of similarity". Evolution, in this context, helps us to explain induction. That means to explain the assertion "Conclusions that are drawn inductively are normally correct." Quine presupposes the latter assumption. He does not show why induction is justified, but rather, how induction-taken as a fact - can be explained by induction. (I leave circularity-objections aside.) Furthermore the parlance of "subjective norms of similarity" contradicts Quines so called "slogan of empiricism" (Quine 1995b, 27): Nothing is in mind (has been understood) that has not been prior in the senses (i.e., accessible by sensory perception). If "subjective norms of similarity" are (parts of) innate structures of cognition, then the "slogan of empiricism" has to be revisited. If constructive cognitive performance of the brain is at least approximately as important as proponents of evolutionary epistemology, neuro-scientific results or philosophers like Michael Pauen, Olaf Breidbach, Gerhard Roth, Thomas Metzinger or Antonio Damasio suggest, then not too much remains of this slogan.

Finally Quine's assumptions about what science-however fallible-has found out are not true. He asserts that we only receive information over the world by causal effects of our sensory receptors (Quine 1995b, 27). 
2.2. Against Quine: Relations between normativity and empiricism

I will only discuss one of Quine's falsities, namely his understanding of empiricism as the supreme norm of science. (I leave the problem of identifying "ok-sciences" aside. Quine's proceeding is quite restrictive.)

One starting point of Quine's argumentation is the following premise: Science is not accountable to any higher tribunal that may judge over science. I agree only for the sake of the argument. (In fact Quine seems to confound "science" and "reason".) Let us have a look of Quines austere view on norms. He actually sees predictions of an observation to test a theory as one norm (Quine 2000, 122). Further norms are conservatism, universality, simplicity, falsiability and "modesty" of a hypothesis, "anecdotes" (Quine) told by the history of science, more mathematicalformal problems, error margins and probability values (Quine 1995b, 27ff). Again, the supreme norm is empiricism (Quine 1995b, 29). It is part of science, and the "norm" of empiricism is also part of science and consequently fallible. That is-to put it mildly-astonishing.

The use of "norm" is not very precise. More than this: If empiricism is more sophisticated than "We do act by collecting experience, making observations or whatever good empiricists do", it is not a part of science but rather belongs to the philosophical area of understanding how scientists operate and gain their scientific knowledge. If empiricism furthermore asserts "We should act like good empiricists" (see above), then a number of norms are enclosed (e.g. "You should prefer observational data about the world compared to reasoning"). Are norms fallible? No. Some norms might be superfluous ("Men must not bear children" is a good candidate), its strict adherence sometimes has undesirable consequences ("Never lie, even if you could save a persons life if and only if you tell a lie"). A norm could be not enforceable or counterproductive. Quine's pragmatic view, combined with an absence of a keen sense of norms, forces him to underrate the relevance of norms: It is true that we need norms in the area "heuristics of obtaining hypotheses". But that is not the whole story. In a broad sense, Quine's epistemology is normative (see e.g. Beyerstein 2005). But it is insufficiently normative. What are the aims of science? How do we judge which processes are superior to other regarding a belief as knowledge? Which social factors influence science? Which rational 
arguments should we accept on the long way from sensory radiation of our body-surface to the enormous theoretical output? These questions desire an elaborated understanding of norms.

Let us assume for one moment that these norms are dispensable. Even if we concede that Quine is initially right with most of his assumptions about empiricism, one critique remains. The data of science is the "neural input" (Quine 2000, 125). Whatever the correct way of creating theories may be, only at the edge of our "network of beliefs" our "empirical checkpoints" stay in contact with the empirically accessible world. The task of naturalistic epistemology is doing "conceptual analysis" (Quine) "within the framework of science itself” (Quine 1995a). Unfortunately, speaking of "conceptual analysis" is fairly unclear. Fortunately for philosophy, however, Quine is doing-despite his naturalistic rhetoric-philosophy, e.g. analysing meaning of terms, evaluating different philosophical theories and controversial arguments, etc. (cf. as a classical source Hahn \& Schilpp 1988, or more recently Keil 2003, 253; 277ff.).

\section{HOW SUCCESSFUL IS NATURALISM?-CAPABILITIES AND LIMITATIONS}

Followers and opponents of naturalistic views in philosophy-be it ethics, anthropology or more theoretical philosophy_may now agree that settling for naturalism does not mean committing hara-kiri (Sagal 1987) for philosophy. Well, critics might say, that there are many ways to kill this time-honored intellectual enterprise.

To defend some naturalistic theses, I will argue that naturalism is superior to Christian philosophy (3.1), especially when we consider theism (see e.g. Nancey Murphy's "Naturalism and Theism as competing traditions" in this volume). Against Michael Rea I will try to show that even if naturalism is only or mainly a research program, it consists of theses, which can be identified (3.2). By "theses" I recognise propositions-be they philosophical or not—such as "The Universe only consists of matter and fields". Theses like this can be partly proven or at least criticised. Is all the work that analyses arguments against naturalism — and is based on theses at the same time—superfluous? 
Finally I will sketch two limitations of naturalism: In dealing with qualia and free will, naturalism has perhaps been overextended (3.3).

\subsection{Why and in what respects is naturalism superior to theism?}

Nancey Murphy (see this volume) contributes a lucid-of course excursive-paper that focuses on two intellectual traditions, theism and naturalism. This is not the right place to elaborate criteria enabling us to compare long term traditions. To make allowance for historical, social or cultural effects that make these criteria "relative", e.g. "Judging the standards of argumentation in India (500 BC), you have to look at the contemporary logic (500 BC)", I concede that western ratio is not the "one and only" monolithic rational standard made for eternity. Yet theism and naturalism have to be in the same ballpark, because otherwise they cannot compete. For this reason I shall apply approved and widely accepted standards, such as explanatory power, internal and external consistency, prognostic strength, absence of circularity, etc., as straightedges for evaluation. ${ }^{6}$

To begin with: It is - against Murphy—not surprising that naturalism results in atheism or that atheism-at least agnosticism-belongs to naturalistic views. "There is no reason at all [...] naturalism with regard to humans as tantamounts to atheism [...]" (Murphy, in this volume, Chapter 1). There are several reasons why atheism is a consequence of naturalistic views:

(i) Ontological relevance of God.

(ii) No place for God by methodological reasons.

(iii) The "design" of the universe (an essentially metaphysical argument).

(iv) Explanatory power of naturalism.

6 I am no crusader on a mission against theism. The value of theism for believers, its cultural importance, a strong need of religiosity - supplying a metaphysical human need-as an anthropological constant are beyond controversy. I also concede that faith in God enables believers to have an extremely persistent, stable view of the world and even ensures social peace and harmony. My task is to distinguish between our wishes and what is_-according to modern knowledge-convincing. 
(i)-(iv) need of course more argumentative support than I can elaborate here. Here are some illustrative remarks on (i)-(iii).

\subsubsection{Crisis of theism ${ }^{7}$}

To start with (i): How can God show his ontological relevance? A modern ontology_be it reductive or nonreductive physicalism, emergentism, (eliminative) materialism, be it based on supervenience or not-has to decide whether it is essentially monistic, dualistic or if it grasps a plurality of entities, e.g. a realm for mental products such as "numbers" or "theoretical concepts", a realm for "concrete objects, i.e. entirely matter" or a realm of entities existing in souls and so on. If we understand "God" not as a metaphor, but rather as concrete, then his ontological status has to be explained. Murphy's access tries to stipulate theistic views with physicalism. The amazing result is consequently a version of physicalism for Christians. We are "complex physical organisms, imbued with the legacy of thousands of years of culture, and, most importantly, blown by the Breath of God's Spirit; we are Spirited bodies" (Murphy 2006, ix).

"Spirit" is a "bridging word", because in ordinary language we understand what we mean. "Esprit" in French e.g. means perhaps to have a clever mind. An intellectually inspiring and inspired person has "esprit". For the sake of the argument, I assume that God exists. Otherwise it is

7 Unfortunately here is not the place to reply to Nancey Murphy's views on the four reasons for "Crisis in Christianity". Here is only one short hint: In chapter 2.3, "Natural Evil", Murphy tries to explain the necessity of natural evil as a by-product of natural laws using some "anthropic calculations". Well, not only Leibniz is dead. All "living-in-the-best-world-of-all-possible-world-theories" should be buried. It is true that some "[s]uffering [...] is caused by their operations [natural laws; TS]." But only a cynic_ —or God as the most powerful cynic_-would justify all natural evil as a by-product of natural laws. According to Murphy et al., this "necessary byproduct of conditions [is] built into creation in order that there be creatures who could respond freely and lovingly to God [...]" God could-and if he is a loving or even a most benevolent God-he should have created the world in accordance to natural laws in such a way, that almost every natural evil could be less terrifying. Is it necessary that hundred of thousands die because of floods or earthquakes? Certainly it is not. God could have created us as deterministic persons, determined to think that we have a free will. It would be much easier to respond "freely and lovingly" to God if he had "designed" a better world. "Better" of course can be identified by morally relevant terms depending on our preferred type of ethic, such as happiness or virtues. 
difficult to see how he can do anything. (In fact the burden of proof lies on the shoulders of theism. Ontological possibility does not mean existence. The history of proofs for God's existence is a history of failure.) If we understand God in such a way that God can be conceived by the human cognitive system (brain), then we have to state that we have to interact with God, or vice versa. If God is essentially immaterial, then we should explain how he acts on our brains. Causality in its ordinary notion does not work here. God has to show traces of his existence, and I do not mean "miracles", but traces left after or at just the moment when we become "spirited bodies". Taken this parlance serious, we should give a proper concept for non-causal interaction or an argument that accounts for how God does act here. I would be really confident, if there was good evidence of empirical proof or-still convincing — an argument by reason.

Let us talk about (ii): A strong ontological naturalist (cf. chapter 1.1) would deny the need of any supernatural realm. Why should we accept such a view? I will just outline some arguments from Mario Bunge and Martin Mahner (2004, 226f.). A scientist (and-at the same time-a defender of theism) who does not expel supernatural entities out of the universe might say: "This experiment (or this argument) failed because the entity A has not (or has) intervened." There is no sound argument for this rather strong ad-hoc-hypothesis. Our scientist (analogous to the philosopher) might even assume that theories, predictions, etc., fail, because entity A did calibrate his measuring apparatus incorrectly. The risk of immunization against critique is obvious.

One more reason for rejecting "God" as an ontologically respectable entity is ontological austerity (see Ockham's razor): If we speak of "God" and "the devil" (e.g. as an fallen angel), then we could also accept the devil's grandmother and other entities leading to ontological rank growth (see Bunge \& Mahner 2004, 11). ${ }^{8}$

Furthermore we and the observable parts of our world are structured. We observe regularities and are able to predict the behavior of natural systems. If we assume supernatural entities, then by definition we could not have any access to them. Apart from miracles, we could not know

8 Serious ontological problems of e.g. naturalism as materialism remain: How does Beethovens 9th symphony exist? How do numbers exist? 
anything about such entities, because they are not bound by mundane regularities, e.g. laws of nature.

Last but not least, supernatural Gods, angels or demons could explain everything. A (scientific) theory should have great explanatory power, i.e., it should explain a couple of things but not everything. A theory that explains everything also does not exclude anything and consequently has no explanatory power (less excursive than the last two passages are Mahner 2002; Bunge \& Mahner 2004).

I will now outline argument (iii): The assumption of a "sparingly furnished universe" as a consequence of an naturalistic ontology allows some wide implications. Like Franz Josef Wetz, we can see fundamental questions about our world-view ("weltanschauliche Fragen") following a "more metaphysic naturalism" (Wetz 2003a, 42). Human beings are-in this view-unimportant agents in an aimless and senseless universe that is ruled by blind natural forces. This senseless universe (nature) is everything that exists. "It is the look, the design" or the physiognomy of the physically constituted universe" that make the old notion called creation loosing its plausibility (Wetz 2003b, 70). Though the existence of God is logically possible, there is no sound argument for this pure possibility. We see some serious consequences interpreting ontological aspects (the "furniture of the universe", or of the world we are living in; see e.g. Wetz 1994; Kanitscheider 1995). To put it in the words of Kanitscheider $(1995,67)$ :

Today there is strong evidence for the estimation, that all these pluralistic ontologies, which had the historical function, to separate men in at least some sub-functions from the context of nature, were metaphysical illusions [italicised in the original; TS], corresponding to an urgent desire of sense. Under the pressure of [scientific facts these illusions cannot be maintained].

\subsection{Naturalism: A yielding, progressive research program?}

My task is "only" to show that a kind of methodological naturalism is in fact a progressive research program. My standards for success are: Explanatory power, capacity of problem solving and potential to integrate

9 "Design" in this notion should be understood in a broader sense, and not the way it is found in current fields of discussion like "intelligent design", creationism or teleological theories in biology and so on. 
new questions and fields of research. One question always is: Given these criteria, is a naturalistic approach more successful than a competitive one?

Again, methodological naturalism in this context means that scientific (and other!) methods and results are indispensable for philosophers. Against Michael Rea (Chapter 3 of his paper in this volume), naturalism is not "inextricably tied to scientific realism by virtue of treating the methods of science as basic sources of evidence" (against this view see e.g. Sukopp 2006a). Naturalists are sometimes instrumentalists or prefer an internal realism or a hypothetical realism. A naturalist like Gerhard Roth prefers constructivism - which is, in the philosophical landscape, not too far from realism!

Second, the ontological austereness of naturalism does not force it to neglect everything beyond physical objects (see e.g. Bunge \& Mahner 2004). Science does not solve all the ontological problems (see e.g. Searle 1997).

My argument in favor of naturalism shows that naturalists are not tied to "scientific realism", but have to consider science as relevant for philosophy. Ulrich Frey (see his paper in this volume) gives an example for a naturalistic Philosophy of Science that is based on empirically accessible data on cognitive abilities of scientists. Contrary to Ulrich Frey, I have serious doubts that such a Philosophy of Science (labeled the "Naturalistic account of scientific errors and its consequences"; see Chapter 3 of Frey's paper) tells us the whole story. But in most respects the cognitive approach is fruitful, because of

(i) its explanatory power;

(ii) its power of problem solving and

(iii) its capacity of integrating new question into an old discipline of philosophy.

(i): A cognitive approach chosen by Frey could show empirically why scientists underlie mechanisms such as framing effects or failure by deficient reducing of complexity. What we know through cognitive science (cognitive psychology) is relevant in Philosophy of Science. Top-down, all-over rules for instance, like the methodology of critical rationalism, should consider cognitive abilities. We do have problems leaving the 
paradigm of well-tried theory behind and therefore hesitate and refuse to give new theories a chance.

(ii): Historical case studies give strong evidence in support of the thesis that "natural science like cognitive psychology and evolutionary biology can offer good descriptions and explanations of phenomena that are of interest in the philosophy of science" (Frey 2007, beginning of Chapter 4; italicised in the original, TS). This cognitive approach is a more powerful instrument than e.g. rational reconstruction or other, rather formal, criteria to evaluate and compare theories. It shows that scientists are subject to cognitive restrictions, it analyses what types of limitations are relevant and it offers evolutionary explanations. Evolution should not be "the instrument par excellence", because if your only instrument is a hammer, then the whole world looks like a nail. To use another metaphor: You hit the wall with your hammer, and after damaging it heavily, you have finally banged the nail into the wall. Really convinced, you declare: "Look at my proper, deliberately chosen tool". Let us stick to facts again. If brains are evolved systems underlying the same processes-like selection and adaptation-, if we take evolutionary theories to be the best theories that explain biological limits, and if cognition is entirely biologically determined, then the conclusion is unspectacular: failures, (cognitive) prejudices, beaten paths exert influence on scientific practice.

Now to (iii): It is widely accepted that certain disciplines-like biology or psychology_are philosophically relevant, because they raise similar questions. One of these questions is: By which processes do we acquire (justified) beliefs? I would like to underline the integrating potential of a cognitive approach quoting Hilary Kornblith (1994):

Even granting for the sake of the argument that in principle it is possible to answer epistemological questions a priori, epistemological truths are anything but obvious. It would be foolhardy not to subject epistemological theories to empirical tests. If scepticism is to be rejected, then epistemology and psychology impose significant constraints on each other. The best way to develop epistemological theories is thus to employ these constraints in a way that allows us to prod the theory along by confronting it with empirical tests.

Moreover: psychology and epistemology could mutually benefit from an approach that makes allowance for empirically accessible factors like a) 
invariance of errors or b) universality of some cognitive mechanisms such as linear-problem-solving, neglecting side effects, long term effects or feedback-loops (Frey 2006, 89; Frey 2007, Chapter 5). The agenda of epistemology contains at least three questions:

(1) By which processes do we acquire (justified) beliefs? (see above).

(2) By which processes should we acquire (justified) beliefs?

(3) Are the processes by which we acquire (justified) beliefs the same processes by which we should acquire (justified) beliefs?

No doubt the answers to these questions depend on the (degree of) reliability of cognitive processes.

\subsection{Limitations of naturalism}

Martially phrased, a naturalist should show which territories he is actually able to control with his troops. ${ }^{10}$ It is out of place to think that naturalism is

${ }^{10}$ In Sukopp 2006b I offered an overview by classifying antinaturalistic arguments. I suggested that the best arguments attack fundamental naturalistic premises (namely methodological, epistemological and metaphilosophical arguments). They criticise (scientific) realism or some normative premises that cannot be justified within science itself. Finally, we find on the agenda of some critics the status of reason. We are in the midst of old disputes. Those critics who disagree with naturalistic premises pick up the following problems (see e.g. Putnam 1982; Keil 1993; most of the papers in Bartelborth 1996; Moser \& Yandell 1996; Haaparanta 1999; Hartmann \& Lange 2000; Goebel 2003 (2005); Graefrath 2005; Loeffler 2005; Wagner \& Warner 2005):

1. Inconsistency.

2. Circularity of conclusions.

3. Missing or at least inadequate opportunity to consider normativity.

4. Neglect of any form of apriorism (a moderate apriorism is hold to be true by some naturalists, e.g. Kitcher).

5. Antipsychologism.

6. (Strong) replacement thesis (attacked also by naturalists, e.g. Almeder).

I offer the following scheme of problems resulting from naturalistic premises:

1. Against realism (not all naturalists prefer a certain version of realists): constructivism, instrumentalism, idealism. 
a solely successful affair. In this paper I only can outline two examples that show naturalistic failures or-which would be a more striking argument against naturalism-intrinsic limitations.

\subsubsection{The naturalisation of recalcitrant phenomena: Qualia}

Qualia behave like a stubborn horse in the eye of a naturalist. (Some naturalists behave like Cowboys trying to ride a stubborn horse.) What it is like in first-person-view to feel pain or to play ping-pong is not the same as to look at fNMR-diagrams (functional Nuclear Magnetic Resonance), a modern and powerful instrument to look "inside the brain". What does this mean? It means that we see "neuronal correlates" to more or less active areas of the brain, which are-e.g. in the case of fNMR-oxygenated. What it means to say "I feel pain" is part of ordinary experience. Science may help to understand what cerebral processes are necessary to say "I feel this tooth aching", but cerebral processes alone do not pinpoint sufficient conditions for this highly theoretical statement. We cannot locate the area that is "responsible" for saying "I" or for knowing if we are justified to say "I". Perhaps Thomas Metzinger (1995, 2003, 2004) is right by pointing out that there is no instance or centre "self" that says "I", but rather a system of self-representations of a certain type. I do not think that naturalism is fruitless in this area. I am simply of the opinion that naturalists should keep in mind what philosophical conclusions we really can draw from empirical results. That means, for instance, that phenomenological and other nonnaturalistic views cannot be denied.

\subsubsection{A remark on neurology and philosophy of free will}

Shouting "Eureka" sometimes makes the shouter feel better. The sweeping arising from the feature pages of well-known German newspapers occasionally sounds like "Eureka". Free will was even worth making the headlines. Why? Because of a bold assumption that "the" problem of free

2. Against terminological pre-decisions, e.g. the naturalistic notion of nature (see e.g. Keil 1993, 360: "Who does not like in no case to speak about 'nature' should remain silent about naturalism.").

3. Against the status of reason/experience: empiricism-rationalism debates, externalism vs. internalism. 
will is empirically solved (A). No such free will exists. Again, I do not neglect efforts made in the "Neuro-Philosophy of free will" only because I reject thesis A.

There is no doubt that people can be "influenced to act in a certain way". But that is not the same as to demonstrate if an action is performed according to someone's free will (choice) or if it is not.

I really do not know of any experiment that gives strong evidence of argumentative leave-taking of free will. I have to insist-though I am not convinced that we have some capability to "decide according to our own free will"- that the adequacy of free will-concepts has not yet been empirically decided. My task is just to sketch a sufficiently complex situation for evaluating if person A acts according to his or her "free will". This situation should not be simplified arbitrarily just because the quantity of potential parameters in psychological experiments has to be restricted or the situation can only be accessible to neural-psychological interpretation if it is simplified. More precisely: An experiment that gives evidence for the strong thesis "Free will is just an illusion" should meet the following requirements:

(1) Against his/her (rational) preferences, motivations, etc., person A chooses to perform an action, e.g. action 1.

(2) Theoretically A could have decided to take alternative 2. We need two (or more) alternatives $(1,2,3, \ldots)$ which are-at first sight-on a par.

(3) Neural correlates of the relevant brain areas-such as the limbic system-should be identified to demonstrate the ineffectiveness of preferences (motivation) mentioned in 1 . (Not to have free will means e.g. that these more or less rational preferences do not take effect.)

(4) Before the determined action (the action that shows the absence of "free will") is carried out, I would like to see neural correlates of deliberations such as preferences, motivation (see again 1 in this list). After this, a determined-e.g. preconscious process-assumes the leadership. 
(5) What does "action potential" mean in this context? Can we properly correlate "action potential" to "carrying out the action"? I invite scientist to think more about the meaning of terms ("action", "influence", "action potential"), because they are suggestive.

Denying free will and remaining silent about limiting experimental preferences, deliberations about which alternative we could have chosen in the experiment (see again 1 in the list), is suspicious. Such an approach is not philosophically reflected, because it anticipates interpretations.

One remark concerning interpretations: An experiment that suffices conditions (1) to (5) has to be interpreted with semantic caution. Winfried Löffler $^{11}$ gave an impressing example of how slight (and obvious) misunderstandings, wrong quotations, dubious reinterpretations of terms and so can on lead to "Eureka": "We can demonstrate empirically that free will is an illusion."

To put it in one sentence: Current experiments are much too simple to simulate real-life situations in which actions could be carried out through someone's free will (or not).

\section{CONCLUSION}

I thus summarize:

(1) Naturalism covers a wide range of positions, which can be identified as theses within research programs or as claims like "We can interact with all existing entities". This claim means the rejection of a supernatural sphere or realm. A naturalist sees cognitive processes, and therefore epistemological results, as natural phenomena, partially explainable by sciences (and humanities!). That is one short formula for naturalism on the different levels: ontology, methodology, epistemology (in the narrower sense).

11 I refer to Löffler's talk at the $29^{\text {th }}$ Wittgenstein-Symposium on $12^{\text {th }}$ of August 2006 , titled "What naturalists always knew about freedom: A case study in the narrative sources of "scientific facts"”. 
(2) Naturalism does not rely on trivialising philosophy, neither by saying "Science itself teaches us", nor by misconceiving naturalism as a self-evident position such as "Philosophers should sometimes take scientists seriously".

(3) Only a few naturalists - and unfortunately some more nonnaturalists - still think that Quine is a standard naturalist or even its prototype. Quine's naturalised epistemology is problematic in many respects. He is incoherent, or even worse, inconsistent, cannot face normative challenges, misunderstands "empiricism" as a norm, etc.

(4) I argue that we can disband theism in comparison with naturalism. Among a lot of "rearguard action", one move of contemporary theism is the assertion that tries to reconcile theism with naturalism. Theism and naturalism dissent. They cannot both be true! In respect of explanatory power, economy, and plausibility, as well as for several other reasons, naturalism is superior to theism.

(5) Where is naturalism successful? Cognitive approaches to Philosophy of Science and epistemology give examples for philosophical relevance of scientific methods and results.

(6) Philosophers are no scientists and some scientific shortcomings are misleading. Anyone who claims that "free will" is dispensable due to experiments that prove this should pause for a moment and think e.g. about the adequacy of the experimental situation.

(7) To answer the question of this volume: Yes, naturalism is successful in some respects. Yet if we adopt some ultimate criteria for success (see Rea 2007, Chapter 1), like "immediate acquisition of wealth and happiness", simply because of "adopting" naturalism, then naturalism is not successful. By the way, it is comforting for naturalists-and particularly for their opponents-that "non-naturalists [do not] spontaneously burst into flames" (Rea 2007, Chapter 1). 


\section{REFERENCES}

Almeder, R. 1990: "On naturalizing epistemology." American Philosophical Quarterly 27, 263-279.

Almeder, R. 1998: Harmless Naturalism: the limits of Science and the Nature of philosophy. Chicago, La Salle: Open Court.

Audi, R. 1998: Epistemology: a contemporary introduction to the theory of knowledge. London, New York: Routledge.

Bartelborth, T. 1996: Begründungsstrategien: Ein Weg durch die analytische Erkenntnistheorie. Berlin: Akademie Verlag.

Beyerstein, L. 2005: Why Naturalized Epistemology is Normative.

http://majikthise.typepad.com/majikthise_/files/en_20050108_blog.pd f (17.05.2007).

Bunge, M. and Mahner, M. 2004: Über die Natur der Dinge. Materialismus und Wissenschaft. Stuttgart: Hirzel.

Frey, U. 2006: "Is naturalism progressive? A naturalistic approach to the Philosophy of Science.” In: Gasser, G. and Kanzian C. (eds.) Papers of the $29^{\text {th }}$ International Wittgenstein Symposium "Cultures: ConflictAnalysis-Dialogues.” Kirchberg am Wechsel: Austrian Ludwig Wittgenstein Society, 88-90.

Frey, U. 2007: "Naturalized Philosophy of Science: A cognitive approach."

In: Gasser, G. (ed.) How successful is naturalism? Frankfurt am Main: Ontos.

Goebel, B. 2003: "Probleme eines philosophischen Naturalismus." In: Goebel, B., Hauk, A. M. and Kruip, G. (eds.) 2005, 23-42.

Goebel, B., Hauk, A.M. and Kruip, G. (eds.) 2005: Probleme des Naturalismus: Philosophische Beiträge. Mentis: Paderborn.

Goldman, A. 1994a: "What is Justified Belief?" In: Kornblith, H. (ed.) Naturalizing Epistemology. Cambridge, MA: MIT Press, 105-130.

Goldman, A. 1994b: "Epistemic Folkways and Scientific Epistemology." In: Kornblith, H. (ed.) Naturalizing Epistemology. Cambridge, MA: MIT Press, 291-316.

Goldman, A. I. 2006: "Social Epistemology." Stanford Encyclopedia of Philosophy (substantively revised version).

http://plato.stanford.edu/entries/epistemology-social/ (17.05.2007). 
Gräfrath, B. 2005: "Biologismus in der Ethik und Erkenntnistheorie." In: Goebel, B., Hauk, A.M., and Kruip, G. (eds.) Probleme des Naturalismus: Philosophische Beiträge. Paderborn: Mentis, 101-110. Haaparanta, L. 1999: "On the possibilities of naturalistic and of pure epistemology." Synthese 118, 31-47.

Hahn, L. E. and Schilpp, P. A. (eds.) 1988: The Philosophy of W.V. Quine. La Salle, IL: Open Court (The Library of living Philosophers Vol. XVIII).

Hartmann, D. and Lange, R. 2000: "Ist der erkenntnistheoretische Naturalismus gescheitert?” In: Keil, G. and Schnädelbach, H. (eds.), 144-162.

Hedrich, R. 1998: Erkenntnis und Gehirn: Realität und phänomenale Welten innerhalb einer naturalistisch-synthetischen Erkenntnistheorie. Paderborn: Schöningh.

Isak, R. (ed.) 2003: Kosmische Bescheidenheit. Was Theologen und Naturalisten voneinander lernen können. Freiburg: Katholische Erzdiözese Freiburg.

Kanitscheider, B. 1995: Auf der Suche nach dem Sinn. Frankfurt am Main and Leipzig: Insel.

Keil, G. 1993: Kritik des Naturalismus. Berlin and New York: De Gruyter. Keil, G. and Schädelbach, H. 2000: "Naturalismus." In: Keil. G. and Schnädelbach, H. (eds.) Naturalismus: Philosophische Beiträge. Frankfurt am Main: Suhrkamp, 7-45.

Keil, G. 2003: "'Science itself teaches'. A fresh look at Quine's naturalistic metaphilosophy." Grazer philosophische Studien 66, 253-280.

Koppelberg, D. 2000: "Was ist der Naturalismus in der gegenwärtigen Philosophie?" In: Keil, G. and Schnädelbach, H. (eds.), Naturalismus. Philosophische Beiträge. Frankfurt am Main: Suhrkamp, 68-91.

Kornblith, H. 1994: "Introduction: What is Naturalistic Epistemology?" In:

Kornblith, H. (ed.) Naturalizing epistemology. Cambridge, London: MIT Press, 1-11.

Kornblith, H. 2002: Knowledge and Its Place in Nature. Oxford: Clarendon Press.

Koskinen, H. J. 2004: From a Metaphilosophical point of view. A study of W. V. Quine's Naturalism. (Acta Philosophica Fennica Vol. 74). Helsinki: Hakapaino Oy. 
Laudan, L. 1987: "Progress or Rationality? The Prospects for Normative Naturalism." American Philosophical Quarterly 24, 19-31.

Laudan, L. 1996: Beyond Positivism and Relativism : theory, method and evidence. Boulder, CO: Westview.

Löffler, W. 1999: "Naturalisierungsprogramme und ihre methodologischen Grenzen." In: Quitterer, J. and Runggaldier, E. (eds.) Der neue Naturalismus - Herausforderungen an das christliche Menschenbild. Stuttgart: Kohlhammer, 30-76.

Löffler, W. 2005: "Evolutionäre Ethik und Erkenntnistheorie: Methodologische Voraussetzungen." In: Goebel, B., Hauk, A. M. and Kruip, G. (eds.) Probleme des Naturalismus: Philosophische Beiträge. Paderborn: Mentis, 111-125.

Mahner, M. 2002: "Stichwort: Naturalismus." Naturwissenschaftliche Rundschau 155, 689-690.

Metzinger, T. 2000 (ed.): Neural Correlates of Consciousness - Empirical and Conceptual Questions. Cambridge, MA: MIT Press.

Metzinger, T. 2003: Being No One. The Self-Model Theory of Subjectivity. Cambridge, MA: MIT Press.

Metzinger, T. ${ }^{3}$ 2004: Subjekt und Selbstmodell. Die Perspektivität phänomenalen Bewußtseins vor dem Hintergrund einer naturalistischen Theorie mentaler Repräsentation. Paderborn: Mentis. Moser, P. K and Yandell, D. 1996: "Against Naturalizing Rationality." ProtoSociology (special issue on rationality) 8, 81-96.

Murphy, N. 2006: Bodies and Souls, or Spirited Bodies? Cambridge: Cambridge University Press.

Murphy, N. 2007: "Naturalism and Theism as Competing Traditions." In: Gasser, G. (ed.) How successful is Naturalism? Frankfurt am Main: Ontos.

Putnam H. 1982: "Why reason can't be naturalized." Synthese 52(1), 3-23.

Quine, W. V. O. 1995a: From Stimulus to science. Cambridge, MA: Harvard University Press.

Quine, W. V. O. 1995b: Unterwegs zur Wahrheit: konzise Einleitung in die theoretische Philosophie. Paderborn: Schöningh.

Quine, W. V. O. 2000: "Naturalismus_oder Nicht über seine Verhältnisse leben.” In: Keil, G. and Schnädelbach, H. (eds.) 2000, 113-127. 
Rea, M. C. 2005: "Naturalism and Ontology: A Reply to Dale Jacquette." Faith and Philosophy 22, 343-357.

Rea, M. C. 2007: "How Successful Is Naturalism?” In: Gasser, G. (ed.) How successful is Naturalism? Frankfurt am Main: Ontos.

Sagal, P. T. 1987: "Naturalistic Epistemology and the Harakiri of Philosophy." In: Shimony, A. and Nails, D. (ed.) Naturalistic epistemology. Dordrecht: Reidel (Boston studies in the Philosophy of science; v. 100), 321-332.

Searle, J. R. 1997: Die Konstruktion der gesellschaftlichen Wirklichkeit. Zur Ontologie sozialer Tatsachen. Reinbek bei Hamburg: Rowohlt.

Sosa, E. 1983: "Nature unmirrored, Epistemology naturalized." Synthese $55,49-72$.

Stroud, B. 2001: "The significance of Naturalized Epistemology." In: Dagfinn, F. (ed.) Philosophy of Quine. London: Garland, 455-471.

Sukopp, T. 2006a: Naturalismus - Kritik und Verteidigung erkenntnistheoretischer Positionen. Frankfurt am Main: Ontos.

Sukopp, T. 2006b: "Outline of Arguments against Naturalism: Levels and Classifications." In: Gasser, G. and Kanzian C. (eds.) Papers of the $29^{\text {th }}$ International Wittgenstein Symposium "Cultures: ConflictAnalysis-Dialogues." Kirchberg am Wechsel: Austrian Ludwig Wittgenstein Society, 344-347.

Vollmer, G. 1994: "Was ist Naturalismus? Zwölf Thesen zur Begriffsverschärfung." Logos, N.F. 1, 200-219.

Wagner, S. and Warner, R. 2005: "Naturalismus — Eine kritische Würdigung." In: Goebel, B., Hauk, A.M. and Kruip, G. (eds.) 2005, 43-61.

Wetz, F. J. 1994: Lebenswelt und Weltall. Hermeneutik der unabweislichen Fragen. Stuttgart: Neske.

Wetz, F. J. 2003a: "Der neue Naturalismus. Eine Annäherung.“ In: Isak, R. (ed.) 2003, 41-66.

Wetz, F. J. 2003b: "Naturalistische Bescheidenheit? Kritische Anfragen an das theologische Menschenbild." In: Isak, R. (ed.) 2003, 67-82.

Wrenn, C. B. 2006: "Naturalistic Epistemology." The Internet Encyclopedia of Philosophy. http://www.iep.utm.edu/n/nat-epis.htm (23.10.2006). 